upon Tyne, for their co-operation; to Miss D. Purvis and Mrs. A. Hauxwell for the majority of the analyses; to Dr. T. R. C. Boyde for identifying the methaemalbumin ; and to Mrs. M. Malaghan for secretarial assistance. Dr. S. M. Murray, of the Regional Blood Transfusion Centre, has taken an interest in the study throughout and given much helpful advice, especially in the preparation of this report.

\section{REFERENCES}

Abbas, T. M., and Tovey, J. E. (1960). Brit. med. 7., 1, 476.

Bangham, D. R., Hobbs, K. R., and Terry, R. J. (1958). Lancet, 2, 351. Beecham, C. T., Molthan, L., Boutwell, J., and Rohrbeck, C. W. (1962). Amer. F. Obstet. Gynec., 83, 1053.

Bevis, D. C. A. (1950). Lancet, 2, 443.

(1952). Ibid., 1, 395.

- (1956). 7. Obstet. Gynaec. Brit. Emp., 63, 68

Bourne, G. L. (1962). The Human Amnion and Chorion. Lloyd-Luke, London.

Brzezinski, A., Sadovsky, E., and Shafrir, E. (1961). Amer. F. Obstet. Gynec., 82, 800 .

Dancis, J., Lind, J., Oratz, M., Smolens, J., and Vara, P. (1961). Ibid., 82, 167.

Davies, J. (1960). Survey of Research in Gestation and the Developmental Sciences. Williams and Wilkins, Baltimore.

Derrington, M. M., and Soothill, J. F. (1961). F. Obstet. Gynaec. Brit. Cwlth, 68, 755 .

Fairweather, D. V. I., Murray, S., Parkin, D., and Walker, W. (1963). Lancet, 2, 1190 .

and Walker, W. (1964). F. Obstet. Gynaec. Brit. Cwlth, 71, 48. Gairdner, D., Lawrie, N. R., and Hutcheon, M. (1950). Lancet, 2, 541. Goodlin, R. C. (1962). West. F. Surg., 70, 181.

Halvorsen, S., and Finne, P. H. (1963). Brit. med. F., 1, 1132.

Hibbard, B. M. (1963). Lancet, 2, 642.
Hyslop, R. S., and Whiley, W. (1960). Med. F. Aust., 1, 622.

Lawler, S. D., and Shatwell, H. S. (1962). Vox Sang., 7, 488.

Liley, A. W. (1961). Amer. F. Obstet. Gynec., 82, 1359.

(1963). Ibid., 86, 485 .

McKay, D. G., Richardson, M. V., and Hartig, A. T. (1958). Ibid., 75, 699.

Mackay, E. V. (1961). Aust. N.Z. 7. Obstet. Gynaec., 1, 78.

Mayer, M., Gueritat, P., Ducas, P., and Lewi, S. (1961). Presse méd.,

69, 2493.
Mollison, P. L. (1956). Blood Transfusion in Clinical Medicine, p. 478. Blackwell, Oxford.

Oram, W. J. (1960). N.Z. med. F., 59, 255.

Papadopoulos, N. M., Hess, W. C., O'Doherty, D., and McLane, J. E. (1959). Clin. Chem., 5, 569.

Parkin, D., Murray, S., and Walker, W. (1961). International Investigation of $\mathrm{Rh}$ Antibody Titrations : report to participants.

Pickles, M. M. (1949). Haemolytic Disease of the Newborn. Blackwell, Oxford.

Stempfel, R., and Zetterström, R. (1955). Pediatrics, 16, 184

Viergiver, E., Stroup, P. E., Sheff, M. F., and Westphal, M. (1962). Obstet., Stroup, P. E., Sh.

Villee, C. A. (1957). Gestation. Transactions of 4th Conference Josiah Macy Jr. Foundation, New York.

Walker, A. H. C. (1957). Brit. med. f., 2, 376

and Jennison, R. F. (1962). Ibid., 2, 1152.

Walker, W. (1960). Proc. 7 th Congr. Europ. Soc. Haemat. London, 1959, Part II, p. 1186.

and Bailey, B. M. (1956). F. clin. Path., 9, 52.

- and Murray, S. (1956). Brit. med. F., 1, 187.

二 and Murray, s.

White, D., Haidar, G. A., and Reinhold, J. G. (1958). Clin. Chem., 4, 211.

Wild, A. E. (1961). Clin. Sci., 21, 221.

Witebsky, E. (1948). Blood, Special Issue No. 2, p. 66.

and Mohn, J. F. (1945). F. exp. Med., 82, 143.

Zipursky, A., Pollock, J., Chown, B., and Israels, L. G. (1963). Lancet, 2,493 .

\title{
Examination of Amniotic Fluid in Rhesus Isoimmunization
}

\author{
JOHN G. ROBERTSON,* M.D., F.R.c.S.ED., M.R.C.O.G.
}

Brit. med. F., 1964, 2, 147-151

It is of some importance that the obstetrician who is supervising the pregnancy of a patient with rhesus isoimmunization should be able to determine the severity of haemolytic disease affecting the infant in utero. At the present time the induction of labour before the expected date of delivery is the only measure which can be routinely offered to such a patient in an attempt to prevent the death of the foetus.

Walker and Neligan (1955) considered that $98 \%$ of infants born alive with haemolytic disease should survive if the treatment they received was adequate, and in 1958 Walker stated that with adequate care the neonatal mortality should be as low as 6 per 1,000. Unfortunately, a large number of stillbirths occur each year from haemolytic disease-500 in England and Wales (Lancet, 1958) - and in their series Walker and Murray (1956) reported a stillbirth rate of $10-15 \%$. Tragically, 7 to $8 \%$ of pregnancies in which antibodies had been detected for the first time ended in stillbirth, and it is primarily to prevent these stillbirths that prediction of the severity of the condition is required.

The methods of prediction available include the absolute level of the antibody titre in the maternal blood and the changes in this level, the previous history of the patient with regard to haemolytic disease in her children, the blood group and rhesus genotype of the patient's husband, and radiological examination. As none of these methods was entirely satisfactory, Bevis (1956) investigated the amount of "blood pigment" present in the liquor amnii, obtaining this liquor by inserting a needle through the anterior abdominal wall (Bevis, 1952). The liquor was then centrifuged and examined in a

* Senior Registrar, Simpson Memorial Maternity Pavilion, Royal Infirmary, Edinburgh ; Lecturer, Department of Obstetrics and Gynaecology, University of Edinburgh. spectrophotometer, the optical density being plotted against the wavelength at intervals between 360 and $700 \mathrm{~m} \mu$. The presence of a "bulge" from the expected "straight line" curve between 400 and $500 \mathrm{~m} \mu$ indicated whether or not the foetus was affected by haemolytic disease.

Walker (1957) used this test on 74 patients, and his prediction was correct in $91 \%$ of cases provided the test was carried out at 34 weeks and no distinction was made between " unaffected" and "mildly affected" infants. The actual severity of the condition was not predicted, nor was the management stated. Liley (1960) described the results obtained in 200 tests and reported the onset of premature labour in seven patients, and also two foetal deaths as a result of uterine infection. Cary (1960), McBride (1961), and Robertson (1961) were all impressed by the ease of "amniocentesis," and considered the procedure to be useful in patients with rhesus isoimmunization. Macbeth and Robertson (1961) found that the height of the optical density indicated the severity of the haemolytic disease in the foetus and indicated the optimum time for the induction of labour. Liley (1961) also was able to predict the severity.

Mackay (1961) performed one test on each of 233 patients and examined the liquor for "bilirubin staining." This determined the time of induction of labour. Walker and Jennison (1962) reported a further series of 156 patients with a $91 \%$ correct prediction rate. They did not find that chemical estimation of the bilirubin content of the liquor was satisfactory.

During the five years 1958-62 425 patients with rhesus isoimmunization attended the Simpson Memorial Maternity Pavilion of the Royal Infirmary of Edinburgh. Amniotic fluid was obtained on at least one occasion from 252 of these patients, and the results obtained are reported. 


\section{Treatment and Testing of Liquor Amnii}

Liquor amnii was obtained between 33 and 35 weeks' gestation, whenever possible. A lumbar-puncture needle was inserted into the uterus transabdominally, as described by Bevis (1952). Sedation was not found to be necessary, but the procedure was explained to the patient and $5 \mathrm{ml}$. of $1 \%$ Duncaine solution was injected into the skin and subcutaneous tissues at the proposed site of puncture. After insertion of the needle and the withdrawal of $20 \mathrm{ml}$. of fluid the patient was allowed home.

The liquor was centrifuged slowly at first and then more rapidly for 20 minutes, and then tested in a Unicam SP 500 spectrophotometer. Readings of optical density were taken at $10-\mathrm{m} \mu$ intervals between 360 and $600 \mathrm{~m} \mu$ and then every $25 \mathrm{~m} \mu$ to $700 \mathrm{~m} \mu$, and the results plotted on semilogarithmic graph paper.

As "false-positive" results were sometimes obtained (a bulge when the infant was unaffected) an additional test has been carried out on many occasions since 1960.

\section{Complications of Paracentesis Uteri}

Among the complications reported after paracentesis uteri are uterine infection, the onset of premature labour, penetration or separation of the placenta, and foetal death. In the present series there was no evidence of uterine infection and in no case did labour begin spontaneously within two weeks of the paracentesis, provided this had been performed before 35 weeks. On a number of occasions the placenta was penetrated, causing blood-staining of the liquor, but in all cases the foetal heart was heard after the procedure and no foetal deaths could be attributed to it. (Since these results were collected one foetus has died after paracentesis, blood being obtained during the procedure.)

\section{Diazo Test}

Reagents.-(1) Diazo solution : (a) sulphanilic acid, 1 g./ $1,000 \mathrm{ml}$; hydrochloric acid, $15 \mathrm{ml} . / 1,000 \mathrm{ml}$., water; (b) sodium nitrite, $0.5 \mathrm{~g} . / 100 \mathrm{ml}$. The solutions are freshly made each week, a solution for testing being prepared daily. This is made by adding $0.3 \mathrm{ml}$. of solution $b$ to $10 \mathrm{ml}$. of solution $a$. (2) methyl alcohol.

Method.-After the liquor has been centrifuged the following solutions are added to a test-tube marked "total ": $2 \mathrm{ml}$. liquor amnii, $1 \mathrm{ml}$. diazo solution, and $3 \mathrm{ml}$. methyl alcohol. A second tube is marked "direct" and contains : $2 \mathrm{ml}$. liquor amnii, $1 \mathrm{ml}$. diazo solution, and $3 \mathrm{ml}$. hydrochloric acid. The solutions are allowed to stand for 10 minutes after preparation. Five solutions are tested with a water blank: (I) Untreated liquor amnii ; (II) Liquor with diazo solution and hydrochloric acid-direct bilirubin; (III) liquor with $4 \mathrm{ml}$. hydrochloric acid-control for No. II ; (IV) liquor with diazo solution and methyl alcohol-total bilirubin; and (V) liquor with $1 \mathrm{ml}$. hydrochloric acid and methyl alcohol-control for No. IV.

\section{Assessment of Severity}

There seems to be no entirely satisfactory means of assessing the severity of haemolytic disease, but the following classification, while not ideal, provides a reasonably practical basis.

Unaffected.-The rhesus group of the infant is the same as that of the mother in all respects, or, if different, the direct Coombs test performed on the infant's blood is negative and the infant is clinically unaffected.

Mildly affected.-The rhesus group of the infant differs from that of the mother and the direct Coombs test is positive, or there is clinical evidence of haemolytic disease, but no treatment-exchange or simple transfusion-is required.
Moderately affected.-The infant is affected by haemolytic disease and requires treatment-that is, exchange transfusion-but is not as severely affected as in the "severe" group.

Severely affected.-The infant is serologically affected with a very low cord haemoglobin (under $8.7 \mathrm{~g} . / 100 \mathrm{ml}$.)—anaemia group -or the indirect serum bilirubin rises rapidly, usually more than once, to $20 \mathrm{mg} . / 100 \mathrm{ml}$. or more, despite exchange transfusionshyperbilirubinaemia group. The infant survives.

Rhesus deaths.-The foetus is stillborn and haemolytic disease is confirmed by post-mortem examination as being the cause of death or a very important factor ; or the child dies in the neonatal period from haemolytic disease or from a cause directly associated with exchange transfusion.

It is difficult to devise a scheme for predicting the severity which takes into account the patient's maturity at delivery, the foetal birth weight, the foetal haemoglobin at birth and subsequently, and changes in the level of serum bilirubin. The scheme described is based on the treatment required by the infant, and although the criteria for exchange transfusion vary from hospital to hospital they are fairly constant in the same hospital.

\section{Determination of Severity from Optical-density Graphs}

The severity of haemolytic disease is predicted by examining the optical density between 400 and $500 \mathrm{~m} \mu$, particularly at $450 \mathrm{~m} \mu$. Typical graphs are shown in Fig. 1.

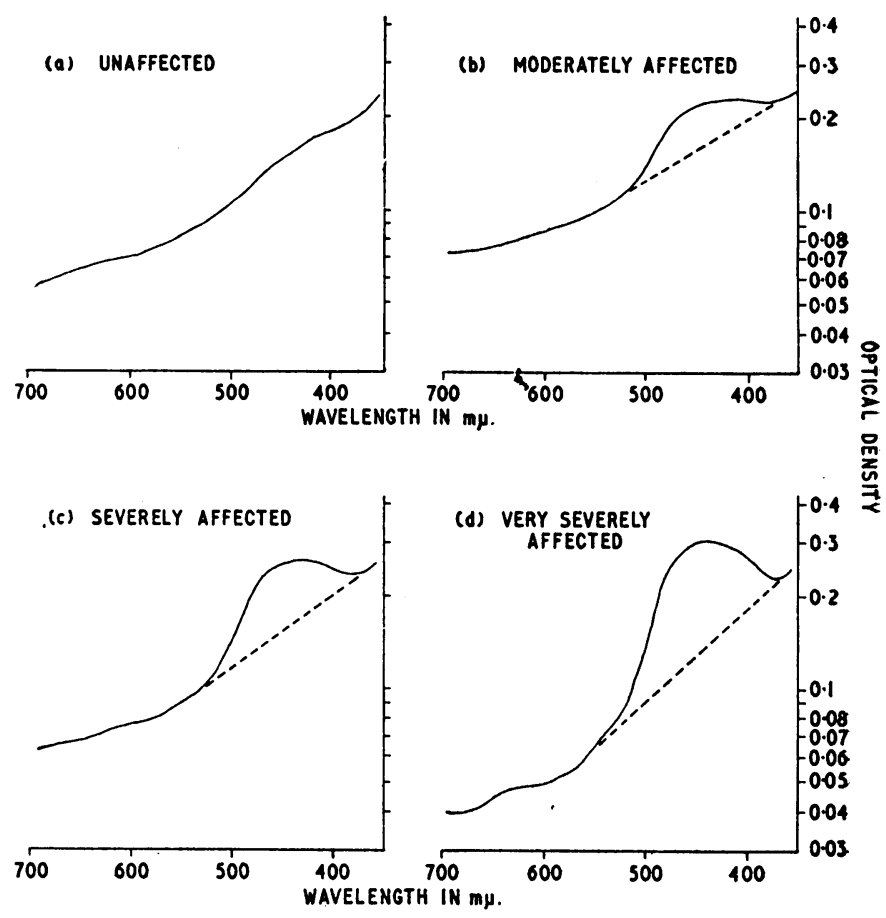

FIG. 1.-Spectrophotometric curves of untreated liquor specimens.

Optical-density Reading at $450 \mathrm{~m} \mu$.-This is not an accurate measure of the degree of involvement of the foetus, as there is a very wide range for all degrees of severity as previously defined. In the present series the optical-density range for the " unaffected and mildly affected" group (considered together, as no special treatment is required and it is difficult to differentiate between the two groups) is from 0.075 to 0.32 , with a mean of 0.178 . The range for moderately affected foetuses is 0.066 to 0.37 with a mean of 0.186 . The difference between these means is not statistically significant. The range for severely affected foetuses is from 0.094 to 0.78 , with a mean of 0.292 . The difference between the means of the moderate and severe groups is highly significant $(P<0.001)$. As the range is very wide, and as there is considerable overlap among the groups, the measurement is not of prognostic value. 
Height of Optical Density at 450 m $\mu$ above the Baseline.The baseline (the broken lines in Fig. 1) assumes that an unaffected curve is present and that the graph shows a "straight-line" curve. It is obtained by joining the points on the graph obtained for the optical density at $400 \mathrm{~m} \mu$ and 500 $\mathrm{m} \mu$. Sometimes a more natural line is obtained by taking the baseline from points before $400 \mathrm{~m} \mu$ and after $500 \mathrm{~m} \mu$. In unaffected or mildly affected foetuses the difference between the optical density on the graph and on the baseline at $450 \mathrm{~m} \mu$ ranges between 0 and 0.02 , with a mean of 0.016 . For moderately affected foetuses the range is 0.02 to 0.07 , with a mean of 0.047 , and the difference between these means is highly significant $(P<0.001)$. In severely affected foetuses the range of optical-density height above the baseline is considerablebetween 0.07 and 0.7 , with a mean of 0.154 -and the difference between the means of the moderately affected and severely affected groups is highly significant $(\mathbf{P}<0.001)$. The greater the height of optical density above the baseline the more severe the haemolytic disease as a general rule.

Height of Optical Density above the Baseline in cm. at 450 $m \mu$.-The optical density is plotted on semilogarithmic graph paper and the actual reading of optical density may be high or low on the scale. For this reason the height recorded above the baseline may be proportionately greater or less than the actual measured optical-density difference. This applies particularly below 0.1 , where a height in centimetres is proportionately greater than the difference in optical density. The range for unaffected and mildly affected foetuses is between 0 and 1 $\mathrm{cm}$., with a mean of $0.6 \mathrm{~cm}$; for the moderately affected foetuses the range is $1-2 \mathrm{~cm}$., with a mean of $1.62 \mathrm{~cm}$. ; and for the severely affected foetuses the height is greater than $2 \mathrm{~cm}$., the mean being $3 \mathrm{~cm}$. The difference between the means of the unaffected and mildly affected and the moderately affected groups is highly significant $(P<0.001)$ and similarly, the difference between the means of the moderately and severely affected groups is highly significant $(P<0.001)$.

\section{False-positive and False-negative Predictions}

An infant was thought to be affected, but.was unaffected, on 42 occasions (false-positives). On eight of these the infant was jaundiced in the neonatal period with high levels of serum bilirubin but no evidence of haemolytic disease due to rhesus incompatibility. In four patients the period of gestation at the time of the test was greater than 35 weeks, and in one the date given was probably incorrect. On three occasions, early in the series, the graphs were difficult to interpret and an incorrect prediction was made.

Since 1960 the diazo test has been used in an attempt to detect the presence of appreciable amounts of indirect bilirubin,

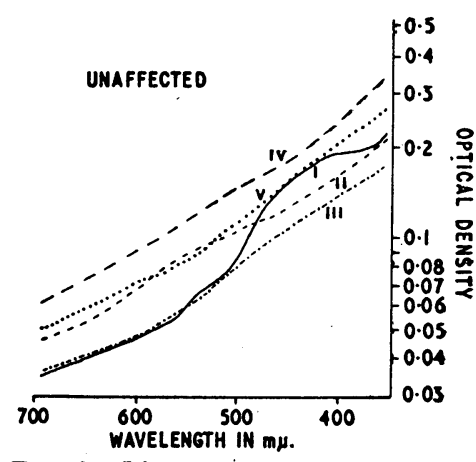

Fig. 2--Liquor curves after treatment with diazo solutions, and ater treatment affected than suggested by untreated liquor. I=Untreated liquor. II= liquor. I $=$ Untreated liquor. II $=$
Liquor + diazo. III $=$ Liquor + hydro$\begin{array}{ll}\text { Liquor }+ \text { diazo. } & \text { III }=\text { Liquor + hydro- } \\ \text { chloric acid. } & \text { IV }=\text { Liquor + diazo + }\end{array}$ methyl alcohol. $\mathrm{V}=\mathrm{Liquor}+$ hydrochloric acid + methyl alcohol.

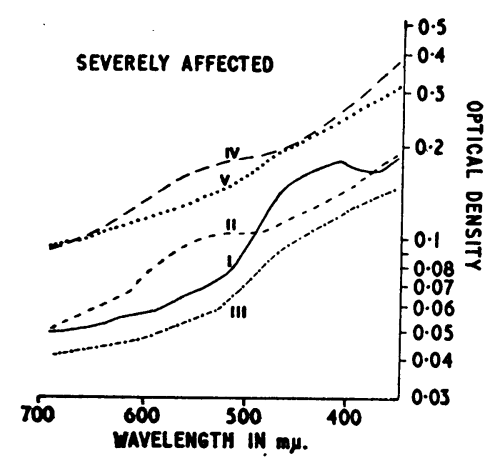

Fig. 3.-Liquor curves after treatment with diazo solutions, and controls. More severely affected than suggested by untreated liquor. Explanation of curves as in Fig. 2. as it was thought that this might eliminate false-positive results. It was sometimes found that the graph of the untreated liquor showed a definite bulge between 400 and $500 \mathrm{~m} \mu$, but that this was associated with direct bilirubin only, as is illustrated in Fig. 2. The bulge between 500 and $600 \mathrm{~m} \mu$, with a peak at $550 \mathrm{~m} \mu$ in curve II, indicated direct bilirubin and, as this is minimal in curve IV, it suggests that very little indirect bilirubin is present and that the infant is unaffected. This was found on 21 occasions in 1961 and 1962.

On a few occasions the bulge in curve IV has been much greater than expected and has suggested that the infant was more severely affected than calculated from the untreated liquor -curve I. This is illustrated in Fig. 3.

Eleven patients were thought to have unaffected infants, although this was subsequently proved wrong. In 10 of these the test was performed after 36 weeks owing to errors in calculation on the part of the patients, while in one no explanation was found.

\section{Results}

The results obtained are recorded in Table I. Because of the difficulty in interpreting the curve after 35 weeks' gestation, these "late tests" are considered separately. The number of " incorrect" predictions corrected by the diazo test are also shown. (The test has been used whenever possible since 1960.)

TABLE I.-Results of Examination of Liquor Amnii with Severity of Haemolytic Disease of Infant

\begin{tabular}{|c|c|c|c|c|c|c|}
\hline \multirow{2}{*}{ Foetal Results } & \multicolumn{2}{|c|}{$\begin{array}{c}\text { Tested before } \\
35 \text { Weeks }\end{array}$} & \multicolumn{2}{|c|}{$\begin{array}{c}\text { Tested after } \\
35 \text { Weeks }\end{array}$} & \multirow{2}{*}{ Total } & \multirow{2}{*}{$\begin{array}{l}\text { Cor- } \\
\text { rected } \\
\text { by } \\
\text { Diazo } \\
\text { Test }\end{array}$} \\
\hline & Correct & $\begin{array}{c}\text { In- } \\
\text { correct }\end{array}$ & Correct & $\underset{\text { correct }}{\text { In- }}$ & & \\
\hline 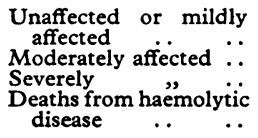 & $\begin{array}{r}37 \\
73 \\
44 \\
9\end{array}$ & $\begin{array}{r}38 \\
7 \\
1 \\
5\end{array}$ & $\begin{array}{r}12 \\
12 \\
4 \\
2\end{array}$ & $\begin{array}{l}4 \\
3 \\
0 \\
1\end{array}$ & $\begin{array}{l}91 \\
95 \\
49 \\
17\end{array}$ & $\begin{array}{r}21 \\
1 \\
0 \\
1\end{array}$ \\
\hline Total & 163 & 51 & 30 & 8 & 252 & 23 \\
\hline
\end{tabular}

* Correction by diazo ignores the direct bilirubin in the liquor.

In Table II the " incorrect" predictions are studied in more detail. In Table III the correct prediction rate in the series is shown to be $86 \%$, while in 1961-62, when the diazo test was used, the predictions were correct in $91 \%$ of cases. The $69 \%$ correct prediction rate in the second time-period, without the diazo test, is probably the result of more exact interpretation of the graphs during this time, with a more definite standardization of the indications for treatment of the infant (largely affecting the mildly affected and moderately affected groups). Also, the knowledge that the diazo test had been performed may have influenced the prediction based on the untreated liquor amnii.

Comparison of Antibody Titres and Liquor Analysis in Predicting Severity.-It is difficult to assess, in retrospect, the prediction made by studying the antibody titres, but it seems that although the liquor prediction has been correct on 60 occasions when the titres were wrong, the titres were correct 29 times when the liquor was incorrect (the diazo test not being used).

Observations on Liquor Curves of Severely Affected. -No correlation between the optical density and either the haemoglobin or serum bilirubin of the infant at birth could be found, possibly because of the time elapsing between the test and the delivery of the infant. In the severely affected group the curves were found to have certain characteristic features. In the hyperbilirubinaemia group a plateau was found between 410 and $460 \mathrm{~m} \mu$ in many cuses, while in nine others a marked hump-peak was found at $410 \mathrm{~m} \mu$, in addition to the plateau (Fig. 4). In the anaemia group there 
TABLE II.-Predictions and Foetal Results in "Incorrect Group"

\begin{tabular}{|c|c|c|c|c|}
\hline \multirow{2}{*}{\multicolumn{3}{|c|}{ Foetal Results }} & \multicolumn{2}{|c|}{ Incorrect Predictions } \\
\hline & & & No. & Prediction Made \\
\hline $\begin{array}{l}\text { Unaffected or mildly affected } \\
\text { Moderately affected } \quad \ldots \\
\text { Severely } \\
\text { Deaths from haemolytic disease }\end{array}$ & $\begin{array}{l}\because \\
\because \\
\cdots\end{array}$ & $\begin{array}{l}\cdots \\
\cdots \\
\cdots\end{array}$ & $\begin{array}{r}42 \\
10 \\
1 \\
6\end{array}$ & $\begin{array}{l}38 \text { moderate. } 4 \text { severe } \\
10 \text { unaffected } \\
1 \\
6 \text { moderate }\end{array}$ \\
\hline Total .. & . & .. & 59 & \\
\hline
\end{tabular}

TABLE III.-Results of Predictions for Two Time-periods, the Diazo Test Being Used in the Second Period

\begin{tabular}{|c|c|c|c|c|c|c|}
\hline \multirow{3}{*}{ Foetal Results } & \multicolumn{6}{|c|}{ Prediction Correct } \\
\hline & \multicolumn{2}{|c|}{$1958-60$} & \multicolumn{2}{|c|}{ 1961-2 } & \multicolumn{2}{|c|}{ Total } \\
\hline & No. & $\%$ & No. & $\%$ & No. & $\%$ \\
\hline $\begin{array}{l}\text { Unaffected and } \\
\text { mildly affected } \\
\text { Moderately affected }\end{array}$ & $\begin{array}{l}33 \\
56\end{array}$ & $\begin{array}{l}66 \\
90\end{array}$ & $\begin{array}{l}16(37) \\
29(30)\end{array}$ & $\begin{array}{l}39(90) \\
88(91)\end{array}$ & $\begin{array}{l}49(70) \\
85(86)\end{array}$ & $\begin{array}{l}54(77) \\
90(91)\end{array}$ \\
\hline incl. rhesus deaths & 33 & 89 & $26(27)$ & $90(93)$ & $59(60)$ & $89(91)$ \\
\hline Total & 122 & 82 & $71(94)$ & $69(91)$ & $193(216)$ & $77(86)$ \\
\hline
\end{tabular}

Figures in parentheses represent results after diazo correction.

were no hump-peaks, but two-thirds of the patients had plateaux (Fig. 5). In nine out of 13 infants dying from haemolytic disease humps and plateaux were found.

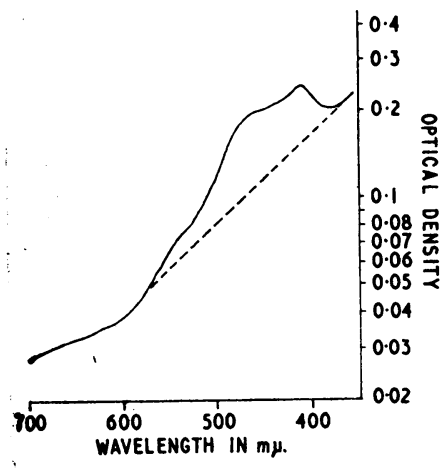

FIG. 4

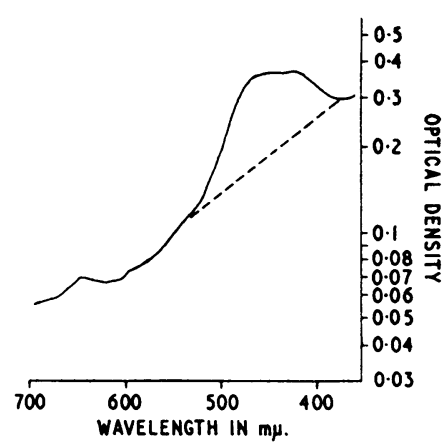

FIG. 5
FIG. 4.-Severely affected-“ hyperbilirubinaemia," with plateau and hump-peak. FIG. 5.-Severely affected-“anaemia," with plateau.

\section{Management of Patients}

After examination of the liquor all the information relevant to the patient's case was studied and a decision regarding the time of induction and the method of delivery made. Unaffected and mildly affected infants were delivered by the expected date of delivery. If a moderately affected infant was predicted labour was induced between 37 and 39 weeks, while if the infant was considered to be severely affected it was delivered between 35 and 37 weeks. Occasionally " heroic" measures were called for before 35 weeks' gestation. If induction was decided upon it was necessary to set a time limit for delivery, and if the induction failed caesarean section was required. Labour was usually induced by artificial rupture of the membranes and oxytocin drip when necessary.

Of the 252 infants delivered after examination of the liquor, 17 died as a result of haemolytic disease. These included two neonatal deaths. Four other infants were affected by haemolytic disease of the newborn but died of other conditions, while two of the infants lost were unaffected. The total foetal mortality in the series was $9 \%$, and the mortality rate from haemolytic disease was $7 \%$.

\section{Discussion}

The most logical method of obtaining information about a foetus in utero during pregnancy is to examine the foetal tissues themselves or some fluid in close proximity to the foetus. The liquor amnii is such a fluid, and any "excretion products" from the foetus are likely to be present in it. If there is haemolysis of the foetal blood by the antibodies, breakdown products will be directly related to the amount of haemolysis, and so it is possible to predict whether the infant is affected or not by haemolytic disease and to estimate the severity of this disease.

The tests are best carried out at 34 weeks, and if blood is routinely tested at 32 weeks from patients who may develop antibodies-those who are rhesus-negative or rhesus-positive having had blood-transfusions, or whose previous infants have had unexplained jaundice-the presence of immunization will be detected in time to arrange for a liquor test. This should be carried out in all patients found to have antibodies. Although the procedure is not difficult, it is made easier by frequent performance. The haemolytic process may become more marked as term approaches, and the degree of severity may be greater than anticipated, but this can usually be allowed for in making the prediction. The prediction of severity is not quantitative but merely gives some indication of the best time to induce labour in order to avoid an intrauterine death or a very severely affected infant. It is essential that efforts are made to reduce the mortality from haemolytic disease, and as this is primarily due to stillbirths, early induction is the only practical therapeutic method available at the present time. Neonatal deaths are rare and with adequate paediatric supervision should continue to be so.

There are other causes of haemolysis in the foetus in utero or after delivery, including drugs taken in the antenatal period. These may give rise to false-positive predictions, as may the presence of direct bilirubin in the liquor. For this reason a diazo test was devised for estimating the amount of indirect bilirubin. A number of incorrect predictions during the last three years were made as a result of testing untreated liquor, but these were corrected by the diazo test.

The difference between the optical density recorded at 450 $\mathrm{m} \mu$ and the baseline recording at the same wavelength gave a range for the different degrees of severity, especially when this was supplemented by the difference measured in centimetres between the two readings. Although there was some overlap, the results were accurate enough to indicate the optimum time for induction to the nearest two or three days. The readings obtained could not be correlated with the birth haemoglobin or serum-bilirubin concentration, probably because of the variable time intervals between the test and delivery. If intrauterine transfusion for the prevention of foetal death from hydrops foetalis becomes a practical procedure (Liley, 1963), liquor examination will be of value in determining those infants for whom transfusion might be life-saving. If a bulge suggestive of a severely anaemic foetus is obtained transfusion might help to keep it alive until premature delivery can be effected. Greater accuracy in deciding suitable conditions for transfusion, however, would be obtained if foetal blood was aspirated and the haemoglobin level determined.

Routine induction of labour at gestations between 35 and 40 weeks has been advocated by various writers (Aaro, 1959 ; Jacobs, 1959 ; Tovey and Valaes, 1959 ; Wiener, 1959 ; Browne, 1960 ; Goplerud, 1961 ; Townsend et al., 1961), and it is generally agreed that immunized patients should be delivered before term. Any procedure which allows a rational timing of induction is of value, and liquor examination would seem to be such a procedure.

\section{Summary}

The method of obtaining and testing the amniotic fluid in patients with rhesus isoimmunization is described, with particular reference to a diazo test which is used to determine the presence of indirect bilirubin. 
The optical density at $450 \mathrm{~m} \mu$ above the baseline is used to predict the severity of haemolytic disease in the foetus, and 193 out of 252 predictions were correct. The diazo test gave the correct result in a further 23 patients. Seventeen infants were lost as a result of haemolytic disease $(7 \%)$.

It is concluded that liquor examination is of definite value in the prediction of severity of haemolytic disease, and in determining the subsequent management of the patients.

I am grateful to Professor R. J. Kellar and Dr. G. D. Matthew for their help and encouragement during this investigation. I am also grateful to the consultant obstetricians in the South-Eastern Region of Scotland for permitting me to obtain liquor from their patients. I also wish to express my thanks to Miss J. Cameron, A.M.I.L.T., for her assistance in devising the diazo liquor test ; to the technicians in the clinical laboratory of the Simpson Maternity Hospital for testing the liquor; and to Sister M. Isdale, of the Simpson Maternity Hospital, for her help in carrying out the tests and in the investigation of the patients. The co-operation of $\mathrm{Dr}$. R. A. Cumming and the staff of the Regional Blood Transfusion Centre and of the paediatricians attached to the Simpson Maternity
Hospital has been invaluable. This material forms part of a thesis for the degree of Doctor of Medicine accepted by the University of Edinburgh.

REFERENCES

Aaro, L. A. (1959). Surg. Clin. N. Amer., 39, 1125.

Bevis, D. C. A. (1952). Lancet, 1, 395.

- (1956). F. Obstet. Gynaec. Brit. Emp., 63, 68

Browne, J. C. McC. (1960). Ibid., 67, 746.

Cary, W. (1960). Med. F. Aust., 2, 778.

Goplerud C. P. (1961). Obstet. and Gynec., 17, 355.

Jacobs, W. H. (1959). Ibid., 13, 314.

Lancet, 1958, 2, 303 .

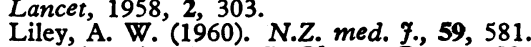

Liley, A. W1). Amer. F. Obstet. Gynec., 82, 1359

(1963). Brit. med. \%., 2, 1107.

Macbeth, R. D., and Robertson, S. B. (1961). Med. f. Aust., 2, 573.

McBride, W. G. (1961). Ibid., 1, 403.

Mackay, E. V. (1961). Aust. N.Z. F. Obstet. Gynaec., 1, 78.

Robertson, S. E. J. (1961). Med. F. Aust., 1, 398.

Tovey, G. H., and Valaes, T. (1959). Lancet, $2,521$.

Townsend, S. L., Mackay, E. V., Shelton, J.' G., Krieger, V. I. and Campbell, K.' I. (1961). F. Obstet. Gynaec. Brit. Cwlth, 68, 382. Walker, A. H. C. (1957). Brit. med. f., 2, 376.

and Jennison, R. F. (1962). Ibid,, 2, 1152

Walker, W. (1958). Vox Sang (Basel), 3, 225.

and Murray, s. (1956). Brit. med. F., 1, 187.

and Neligan, G. A. (1955). Ibid., 1,61 .

Wiener, A. S. (1959). Exp. Med. Surg., 17, 15.

\section{Hand Eczema}

\section{F. RAY BETTLEY,* M.D., F.R.C.P.}

When eczema affects the hands it tends to be disabling as well as uncomfortable ; to the patient it is ever before him, inescapable ; it embarrasses him because it is so often easily visible to others ; and it is common.

The 106 cases of hand eczema which form the basis of this report were in patients seen by me for the first time over a period of 12 months and represent, therefore, about $5 \%$ of all patients attending the dermatological out-patient clinic. Even so, they are selected, since they are only those cases where the hands were originally involved and in which the hand lesion was the primary complaint. Other eczemas, where the hands were later involved as a part of a more widespread eruption, have not been included and would, no doubt, have provided a further substantial number. All the patients in the present series were seen, investigated, and treated by me personally with the main object of forming a consistent assessment of causative factors and of the value of treatment. Final review was carried out 18 to 24 months after first attendance ; seven failed to report for follow-up.

The group contained 56 men and 50 women, a slight difference of no likely significance. The age at onset (Table I)

\begin{tabular}{|c|c|c|c|c|c|c|c|c|c|c|c|c|c|c|c|}
\hline Age (yrs) & -5 & -10 & -15 & -20 & -25 & $-30-3$ & -35 & -40 & -45 & -50 & -55 & $-60 \mid$ & -65 & $|-70|$ & Total \\
\hline $\begin{array}{l}\text { len } \\
\text { 'omen }\end{array}$ & 1 & $\frac{1}{2}$ & $\overline{3}$ & $\begin{array}{l}3 \\
5\end{array}$ & $\begin{array}{l}6 \\
7\end{array}$ & $\begin{array}{l}3 \\
4\end{array}$ & $\begin{array}{l}4 \\
4\end{array}$ & $\begin{array}{l}7 \\
5\end{array}$ & 4 & $\begin{array}{r}11 \\
7\end{array}$ & $\begin{array}{l}7 \\
5 \\
\end{array}$ & $\begin{array}{l}4 \\
2\end{array}$ & 2 & 3 & $\begin{array}{l}56 \\
50\end{array}$ \\
\hline
\end{tabular}

shows a difference in the sexes. In men a peak incidence is found at 46-50 years of age, while in women the age distribution is more level from 16 years onwards; this might be attributed to the effect of housework with its cleansers and primary irritants, but for reasons given below this suggestion cannot be substantiated.

* The Middlesex Hospital and St. John's Hospital for Diseases of the
Skin, London. E

\section{Clinical Groups}

Among the whole series it is possible to define certain clinical groups.

\section{Nummular Eczema}

The term "nummular" is applied to a type of discoid eczema, usually affecting the backs of the hands and fingers, sometimes the forearms, in which the eczematous areas are well outlined with normal skin between. There were 12 men and four women showing this pattern, one case being possibly atopic. None gave positive reactions to routine patch tests.

This group was distinguished by its relatively short duration, often clearing up in the course of some months.

\section{Nickel Allergy}

Calnan and Wells (1956) drew attention to the fact that nickel is a very common cause of epidermal allergy in women in the United Kingdom. They pointed out, too, that these patients are prone to hand eczema even after nickel dermatitis has healed and without identifiable continuing contact with nickel. Six women in the present series were of this kind. All of them knew of their proneness to metal rashes and avoided contact with metals. The duration of their hand eczema was from one month to three years, but nickel sensitivity was of many years' duration.

Nickel sensitivity in men is more often occupational, occurring, for example, in electroplaters. Two men in the present group were found on patch-testing to be nickelsensitive ; one of these gave a history of a rash beneath a wrist- 